\title{
New records for stink bugs (Heteroptera: Pentatomidae) in Puerto Rico, ${ }^{1,2}$
}

\author{
Alejandro E. Segarra-Carmona ${ }^{3}$, Rosa A. Franqui ${ }^{3}$, \\ Hariette Pérez-Martínez $z^{4}$ and Alejandra Morales-Grajales ${ }^{5}$
}

J. Agric. Univ. P.R. 99(2):167-178 2015

\begin{abstract}
We present records for six new stink bug species reported for Puerto Rico. These include two predatory species: Apateticus lineolatus (Herrich Schäffer) and Tylospilus acutissimus (Stảl) (Asopinae); and four phytophagous species: Berecynthus hastator (F.), Chlorocoris tau Spinola, and Acrosternum (Chinavia) ubicum Rolston (Pentatominae), and Alitocoris brunneus Sailer (Discocephalinae). Of these, B. hastator has been identified elsewhere as a vector of palm diseases, and $A$. brunneus appears to be a recent invasive species to Puerto Rico. Species reported here increase the number of stink bug species reported in Puerto Rico from 42 to 48, and the number of genera from 29 to 34 . It is also the first report of a member of subfamily Discocephalinae on the island.
\end{abstract}

Key words: Pentatomidae, Puerto Rico, invasive species

\section{RESUMEN}

Informe de seis especies de pentatomidos nuevas en Puerto Rico

Presentamos los primeros informes para seis especies de pentatomidos en Puerto Rico. Entre ellas se hallan dos especies depredadoras: Apateticus

${ }^{1}$ Manuscript submitted to Editorial Board 13 March 2015.

${ }^{2}$ Research funded by University of Puerto Rico Agricultural Experiment Station's Insect Research Collection (C-415). The authors wish to acknowledge the kind collaboration of Arístides Armstrong, Ángel L. González, Carlos Rosario, and Luis Collazo for allowing access to material in entomology student collections over the past decade. To Dr. Stuart J. Ramos we are indebted for access to the important José A. Ramos private collection. We are also grateful to Dr. Carlos Santos for allowing us to borrow specimens from the Biology Department's INV-COL. We acknowledge the collaboration of students Natanael Valentín, who curated and organized the MEBT pentatomid collection for well over a year, and of Necha Borrero and César Ramírez who actively participated in MEBT accession number assignation and data base maintenance.

${ }^{3}$ Professors, Department of Agroenvironmental Sciences, Agricultural Experiment Station, College of Agricultural Sciences. Mayagüez Campus, University of Puerto Rico. Send all correspondence to alejandro.segarra@upr.edu.

${ }^{4}$ Research Associate, Department of Agroenvironmental Sciences, Agricultural Experiment Station, College of Agricultural Sciences. Mayagüez Campus, University of Puerto Rico

${ }^{5}$ Undergraduate Student, Department of Agroenvironmental Sciences, Agricultural Experiment Station, College of Agricultural Sciences. Mayagüez Campus, University of Puerto Rico. 
lineolatus (Herrich Schäffer) y Tylospilus acutissimus (Stål) pertenecientes a la subfamilia Asopinae. Informamos también cuatro especies fitófagas, tres pertenecientes a la subfamilia Pentatominae: Berecynthus hastator (F.), Chlorocoris tau Spinola, y Acrosternum (Chinavia) ubicum Rolston y un miembro de la subfamilia Discocephalinae, Alitocoris brunneus Sailer. La especie $B$. hastator ha sido identificada en la literatura como un vector de enfermedades en palmas y $A$. brunneus aparenta ser una nueva especie invasora. Estos nuevos informes elevan el número de especies de Pentatomidae informadas de 42 a 48, y el número de géneros de 29 a 34 .

Palabras clave: Pentatomidae, Puerto Rico, especies invasoras

Pentatomidae, commonly know as stink bugs, are a large and wellknown group of over 4,000 described species (Panizzi et al., 2000). Currently, the pentatomidae is divided into eight subfamilies: Asopinae, Cyrtocorynae, Discocephalinae, Edessinae, Pentatominae, Phyllocephalinae, Podopinae, and Serbaninae (Schuh and Slater, 1995). Worldwide, stink bugs are major pests of such crops as rice, legumes, and vegetables. While many species generate losses through their piercing-sucking feeding, others are important vectors of plant diseases. Conversely, members of the subfamily Asopinae are important biological control agents because of their predaceous feeding habits. Predatory stink bugs attack mainly slow-moving, soft-bodied insects primarily of the Lepidoptera, Coleoptera and Hymenoptera. The Discocephalinae are neotropical in distribution, and of no economic importance. Pentatomines contain most of the species in the family, are distributed worldwide and are important plant feeders.

Taxonomically, Caribbean pentatomids have been fairly well studied. For example, recent studies by Pérez-Gelabert and Thomas (2005), and by De los Santos and Bastardo (2013) have advanced an understanding of the group in Hispaniola, reporting 77 species in 36 genera. In Puerto Rico, the last major taxonomic studies of this group were published over 70 years ago by Barber $(1923,1939)$, who reported 32 species belonging to 17 genera in three subfamilies: Asopinae, Edessinae, Pentatominae. Wolcott (1948) added two species, and provided new host plant and locality information for several of Barber's species. Since then, reports by various authors have increased the number of species found in Puerto Rico to 44, including 29 genera (see Sailer, 1952; Rolston and McDonald, 1984; Rolston, 1986; Rider, 1987, 1988 and 1992; Franqui et al., 1988; and Thomas, 1990 and 1992).

The lack of a comprehensive revision of this group in recent years, and the potential threat posed by an economically important invasive species (e.g., Tibraca limbativentris Stål), an important pest of rice recently reported from the neighboring island of Hispaniola, prompted us to examine extant material housed in the main Puerto Rican insect collections. Research presented here is the product of on-going curato- 
rial efforts on the historical Agricultural Experiment Station's "Museo de Entomología y Biodiversidad Tropical" (MEBT) collection, and from research work designed to identify new potential hemipteran vectors of diseases in palms and other tropical crops.

\section{MATERIALS AND METHODS}

Specimens were identified using existing keys and from original descriptions. Insects were examined using an Olympus SZX-12 stereo microscope (magnification 7-90x), and an Olympus BX41 phase-contrast compound microscope (magnification 50-400x). Female genital plates and male pygophores were photographed using a Canon Ti4 camera. Measurements were made using an ocular micrometer. Examination of male genitalia included maceration of dissected abdomens in $10 \%$ $\mathrm{KOH}$. Genitalia were placed on glass slides with glycerin for examination, and photographed using a Canon Vixia HSF21. Digital images

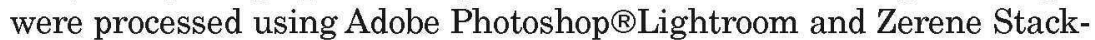
erß software. Specimens examined belong to the following collections: The historical collection at the University of Puerto Rico Museo de Entomología y Biodiversidad Tropical (MEBT); The Invertebrate Collection at the University of Puerto Rico-Mayaguez, Biology Department (INV-COL); and the private collection of Dr. José A. Ramos-Alemar and Dr. Stuart Ramos-Biaggi ("JAR"). Species accounts presented below include basic information on taxonomical synonymy, known geographical and local distribution, relevant biological information, and a list of preserved material housed by MEBT that includes collection label information, sex, and accession number for each insect (in brackets).

\section{RESULTS AND DISCUSSION}

We report new records for six stink bugs from Puerto Rico: Two predatory species (Asopinae): Apateticus lineolatus (Herrich Schäffer), and Tylospilus acutissimus (Stål); and four phytophagous species: three Pentatominae: Berecynthus hastator (F.), Chlorocoris tau Spinola, and Acrosternum (Chinavia) ubicum Rolston; and Alitocoris brunneus Sailer (Discocephalinae).

\section{Subfamily ASOPINAE}

This subfamily contains important predators of insect pests (McPherson, 1982). Asopines are distinguished from other pentatomids by the beak, which has an engrossed and freed first segment, directed away from the head. In Puerto Rico, the most common member of this subfamily is Podisus sagitta (F.) that Wolcott (1948) reports as an insect predator of the cotton leafworm Alabama argillacea Hübner. 
Apateticus lineolatus (Herrich-Schäffer, 1840) [Figures 1A, 2A] Halys lineolata Herrich-Schäffer

DISTRIBUTION: Recorded from the USA (Texas, Florida), Mexico, Central America, and northern South America (Distant, 1884; Thomas, 1992).

REMARKS: Only one specimen of this species exists in the MEBT collection. This is the largest asopine in the collection $(15 \mathrm{~mm})$, and among the largest recorded in the subfamily. The sole specimen is brown with rounded humeral angles. Little is known about its life history. It appears to be common in Mexico, where it has been reported as an important predator of folivorous coleopteran larvae (De Clercq, 2000). Other members of the genus Apateticus Dallas are reported as feeding on lepidopterous larvae (McPherson, 1982).

MATERIAL EXAMINED: PUERTO RICO. Mayagüez: 12.viii.2011. Jorge, K. ( ( ). [MEBT12340].

Tylospilus acutissimus (Stål, 1870) [Figures 1B, 2B]

Podisus accutisimus Stål

DISTRIBUTION: This species was originally described by Stål (1870) from Mexico and Texas. This asopine has also been reported from Central America, Colombia, Cuba, and Hispaniola (De Clercq, 2000; Pérez Gelabert and Thomas, 2005).

REMARKS: Only one individual of this small asopine is housed at MEBT. The specimen is $7 \mathrm{~mm}$, straw colored, with dark eyes, prominent humeral spines, and contrasting red dorsal markings. According to Thomas (1992), the species has varied coloration. Natural prey is unknown, but has been laboratory-reared on lepidopterous larvae. According to Stoner et al. (1974), this species apparently also feeds on plant tissues when its prey is absent.

MATERIAL EXAMINED: PUERTO RICO. San Germán: Rosario Alto. 1.xi.2008. Olivera, V. ( ( ) [MEBT12346].

\section{Subfamily DISCOCEPHALINAE}

Most members of this subfamily were previously placed in the pentatomine tribe Halyini. According to Rolston (1992) discocephalines are "exceedingly dull in appearance, being largely of funereal hues." Until recently they have received little attention from taxonomists, thus their classification is largely undeveloped. The most abundant group of species belongs to tribe Ochlerini from Western Hemisphere tropics and subtropics. Little is known of their life histories. Most species 

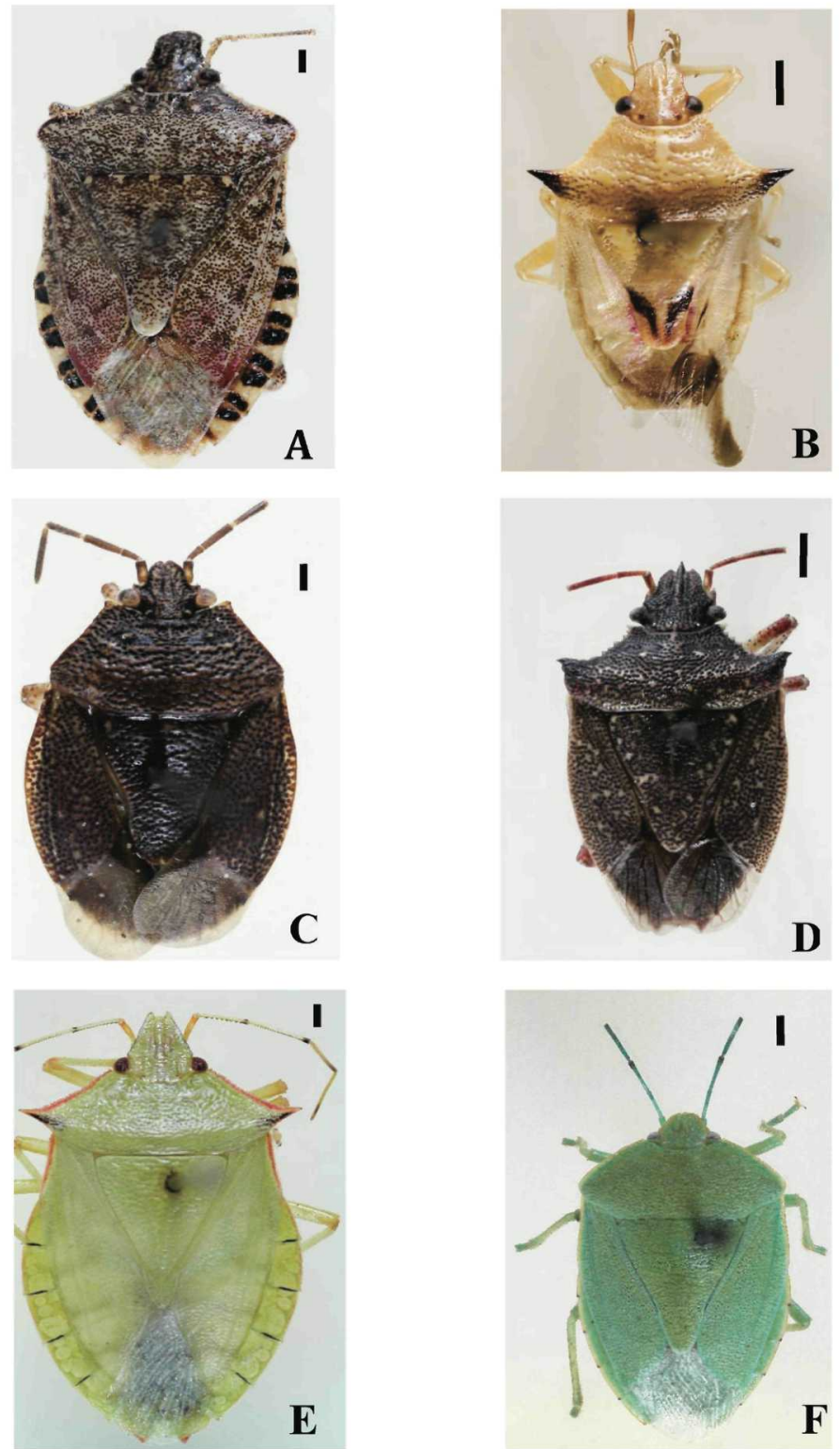

Figure 1. Dorsal view. A. Apateticus lineolatus [MEBT12340]; B. Tylospilus accutisimus [MEBT12346]; C. Alitocoris brunneus [MEBT12350]; D. Berecynthus hastator [MEBT12341]; E. Chlorocoris tau [MEBT12605]; F. Acrosternum (Chinavia) ubicum [MEBT12158]. Bar $=1 \mathrm{~mm}$. 
are generally considered phytophagous, apparently inhabiting forest canopies, and are commonly collected only at light (McPherson, 1982; Rolston, 1992). This is the first record for discocephalines in Puerto Rico.

Alitocoris brunneus Sailer, 1950 [Figures 1C, 2C]

DISTRIBUTION: Holotype from imported Honduran orchids intercepted in New Orleans in 1941 (Sailer, 1950). The species has also been reported from Mexico, Guatemala, and El Salvador.

HOST PLANT RECORD: No additional records exist other than the one on orchids.

REMARKS: There are no collection records for this species before 1999, when an individual was collected by an entomology student in Mayagüez. Recent collection records indicate that the species is now widely distributed on the island. The species is dull brown and 8 to $10 \mathrm{~mm}$ in length. As with other ochlerines, this species is commonly collected at light (Garbelotto et al., 2011), with several local collection records supporting this observation. Little is known about the species biology and, until recently, the taxon had received little attention. Current taxonomical placing is uncertain. Recent systematic treatment by Garbelotto et al. (2013) has demonstrated the paraphyletic nature of Alitocoris Sailer, thus the placement of $A$. brunneus into a new and yet undescribed discocephaline genus has been proposed.

MATERIAL EXAMINED: PUERTO RICO.Adjuntas: 14.x.2011. Crespo, J. (우) [MEBT12382]; Aguada: $18^{\circ} 20.95 \mathrm{~N}$ 67¹3.09W. 4-6.xi.2011. Valentín, N.Ex. UV light. (2 \&) [MEBT08892, 08994];Aguadilla:18.x.2010. Santiago, C. (2o) [MEBT12368-9]; Arecibo: 12.iii.2010. Faria, O. (o) [MEBT12361]; 17.ii.2013. Acevedo, L. () [MEBT12119]; Barranquitas: 2.iii.2010. Berríos, M. (đ) [MEBT12357]; 30.iii.2010. Berríos, M. () [MEBT12358]; Cabo Rojo: 15.iii.2009. Jesús, A. (ô) [MEBT12367]; Boquerón. $18^{\circ} 00.65 \mathrm{~N} 67^{\circ} 10.96 \mathrm{~W}$. 6.x.2011. Segarra, A. Ex. Blacklight. (1우 30) [MEBT08899, 08891, 08893, 08895]; 24.ix.2011. Pérez, C. (q) [MEBT12370]; El Faro. 2.xi.2011. Vigo, J. () [MEBT12371]; Boquerón. 28.iv.2012. Segarra, A. Ex. UV light. ())[MEBT08896]; 21.iv.2013. De Jesús, D.R. ( đ) [MEBT12113]; Ciales: Sector La Grama. 14.iii.2010. Rodríguez, A. (ô) [MEBT12374]; 14.v.2011. Miranda M. (ㅇ) [MEBT12375]; Coamo: Urb. Villa Madrid. 15.x.2011. Morales, K. (o) [MEBT12374]; Guayama: 13.iv.2013. Delgado, C. (ô) [MEBT12366]; Guayanilla: 12.iii.2009. Rodríguez, R. (ठ) [MEBT12364]; 2.viii.2013. Matos, G. (o) [MEBT12111]; Hormigueros: 17.iii.2011. Rodríguez E.Y.I. (q); Rivera, K. No date. (10 1\%) [MEBT12115-16]; Isabela: 8.iv.2013. 
De Jesús, D.R. (ઠ) [MEBT12114]; Lajas: 27.viii.2011. Caraballo, A. (ઠ) [MEBT12385]; Las Marías: 8.ii.2007. Ramos, M. (ô) [MEBT12362]; Maricao: 6.iii.2011. Zayas J.R. (\$) [MEBT12383]; Mayagüez: 5.ix.1999. R. Tamayo. (ㅇ) [MEBT 13081]; 6.ix.2008. Alvarez, A. ( §) [MEBT12354]; 11.xi.2008. Bo. Leguizamo. Echevarría, N. ( (ో) [MEBT12355];13.iv.2011. Rodríguez, E.Y.I. ( $)$ [ [MEBT12372]; 3.iii.2012. Piscina RUM. Miranda, M. (ठ) [MEBT08898]; 26.iv.2013. Edif. Piñero, RUM. Maldonado, A. (\$) [ MEBT12117]; 12.iv.2013. De Jesús, D.R. (ठో) [MEBT12112]; 10.x.2013. Mitchell, M. (ઠ) [MEBT12356]; Moca: 14.ii.2006. Ezequiel () [MEBT12381]; 23.iv.2011. Quintana, E. (10 1ㅇ) [MEBT12379, 012380]; Sabana Grande: 8.x.2013. Torres, A. o) [MEBT12363]; Ponce: 2.x.2011. Rodríguez, R. () [MEBT12384]; 30.viii.2013. Negrón, C.A. (o) [MEBT12118]; San Sebastiân: 19.iv.2009. Santiago, M .

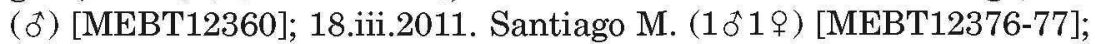
27.iv.2011. Torres N.M. (q) [MEBT12378]; 1.iii.2012. Rodríguez, Y. (\%) [MEBT08897]; 22.ix.2013. Matos, K. (\$) [MEBT12359]; Utuado: 9.iv.2009. Valentín J. (ठ) [MEBT12350]; 29.iv.2009. Feliciano, N. (ㅇ) [MEBT12349]; Vega Baja: 6.iv.2009. De Jesús, L. (ㅇ) [MEBT12365]; Villalba: 16.v.2010. Vega M. (10 1) [MEBT12347-48]; Yauco: 3.v.2009. Torres, T. (2 ㅎ) [MEBT12352-53]; 13.iv.2010. Feliciano, J. (ㅇ) [MEBT12351].

\section{Subfamily PENTATOMINAE}

Pentatomines are the most common stink bug subfamily, and are represented by 34 species in Puerto Rico. The group is largely phytophagous, containing important pests, such as the southern stink bug, Nezara viridula (L.), and the rice stink bugs in the genera Oebalus Stål and Mormidea Amyot \& Serville (Wolcott, 1948; Franqui et al., 1988).

Acrosternum (Chinavia) ubicum Rolston 1983. [Figures 1F, 2F]

DISTRIBUTION: Holotype collected from Bolivia. Also reported from Hispaniola, Colombia, Guyana, Ecuador, Bolivia, Brazil, and the Galapagos Islands (Rolston, 1986).

HOST PLANT RECORD: Host plant records indicate a preference for legumes. Schwertner et al. (2002) reports the following Leguminosae as host plants: Glycine max (L.) Merrill, Canavalia rosea (Sw.), Cajanus cajan (L.) Millsp., Vigna unguiculata, Phaseolus vulgaris L., Crotalaria incana L. and C. pallida Aiton. One Puerto Rican specimen was collected on flowers of Crotalaria sp.

REMARKS: The first collection of this Neotropical species recorded in Puerto Rico is from a specimen collected by Medina-Gaud in 1983. The species can readily be distinguished from other Acrosternum spp. 

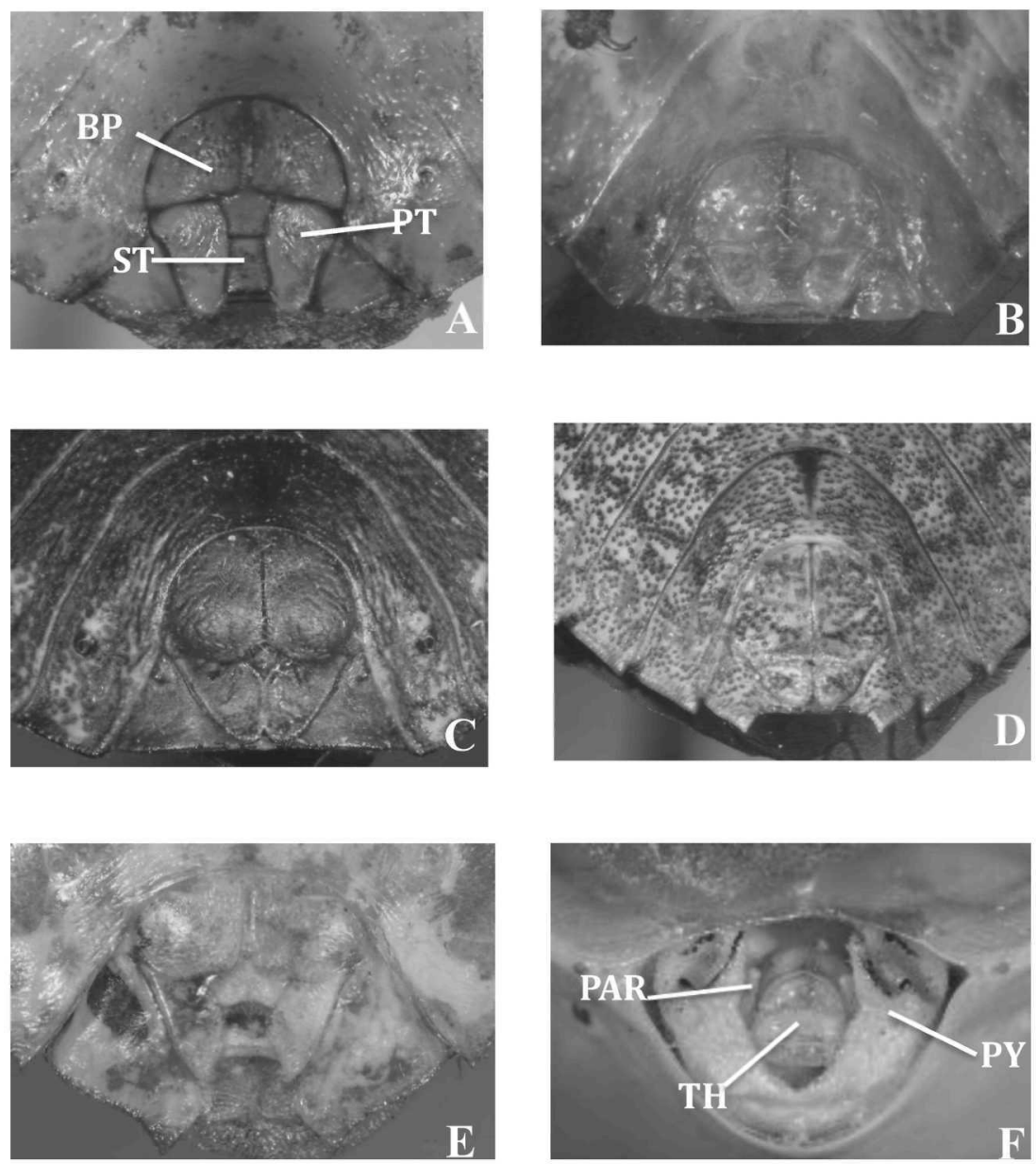

Figure 2 (A-E). Female genitalia. Ventral view:A. Apateticus lineolatus [MEBT12340]; B. Tylospilus accutisimus [MEBT12346]; C. Alitocoris brunneus [MEBT12118]; D. Berecynthus hastator [MEBT12341]; E. Chlorocoris tau Spinola [MEBT12605]; F. Male genitalia. Caudal view. Acrosternum (Chinavia) ubicum Rolston [MEBT12158]. Symbols: BP = Base plate; $\mathrm{PT}=$ Paratergite 9; $\mathrm{ST}=$ Sternite $10 ; \mathrm{PY}=$ Pygophore; $\mathrm{PAR}=$ Paramere; $\mathrm{TH}=$ Theca.

in Puerto Rico by several characters: (1) the distinctive shape of the male's pygophore (Figure 2F); (2) a dull pale green color; (3) a short abdominal process that barely reaches the metacoxal base; and (4) by its black abdominal spiracles. From the paucity in recent collections, it also appears to be the least common Acrosternum species on the island. 
MATERIAL EXAMINED: PUERTO RICO. Aguada: Valle Coloso. 3.ix.2010. Acevedo, A. (o) [MEBT12173]; Arecibo: 6.viii.1986. Medina, S. \& Franqui, R. Weeds on rice fields. "395-86". [MEBT9059] ( + ); Guánica: 15.ii.2010. Toro, B. 20.iv.2010 ठ) [MEBT12158]; 20.iv.2010. Soto, M. (む) [MEBT12137]; Gurabo: 18.iv.1987. No collector info. (ㅇ) [MEBT9038]; Manatí: 10.viii.1983. "Finca experimental de piña" ex: Crotalaria flowers. Medina-Gaud, S. (ㅇ) [MEBT8998]; Jayuya: 19.ii.2009. Costales, E. J. (ㅇ) [MEBT12180]; Rincón: 19.iv.2009. Martínez, L. (ㅇ) [MEBT12171].

Berecynthus hastator (Fabricius, 1798) [Figures 1D, 2D] Berecynthus delirator (Fabricius, 1794).

DISTRIBUTION: This species was described by Fabricius from Guyana ("Cajennae"). Also reported from Mexico, Nicaragua, Panamá, Colombia, Costa Rica, Venezuela, Suriname, French Guyana, and Brazil.

HOST PLANT RECORD: Informed as a possible vector of "hartrot", a lethal disease of coconut palms (Segeren, 1982). Also reported on Rottboellia cochinchinensis (Poaceae) in Guyana (Haywood et al., 1994).

REMARKS: This is a medium-sized (7-8 $\mathrm{mm}$ ), dark brown species. Its distinctive elongated tylus, extending well beyond the juga, is reminiscent of its close and more abundant relatives in the genus Proxys Spinola. Taxonomy for this species is complicated by the fact that $\mathrm{Fa}-$ bricius described it under several different names (Rider and Rolston, 1995). Accordingly, most literature accounts refer to this species by its junior synonym of $B$. delirator. This is likely to be the first record of the species outside Central and South America.

MATERIAL EXAMINED: PUERTO RICO. Cabo Rojo: 12.xi.2008. Luciano, Pamela ( $q$ ) [MEBT12341]; Combate. 22.iii.2010. Rodríguez, M. () [MEBT12343]; Hormigueros: 17.iii.2011. Rodríguez, Y.-I. () [MEBT 12342]; NEVIS. Charlestown. 7.iii.1931. ( ( ) JAR collection.

Chlorocoris tau Spinola, 1837 [Figures 1E, 2E].

DISTRIBUTION: The species was only known from Brazil (Thomas, 1985).

HOST PLANT RECORD: Unknown.

REMARKS: Only one specimen was collected near the Borinquen Airfield in Aguadilla by Dr. Stuart J. Ramos in 1978. The species has not been collected since, and the possibility that this individual was introduced from Brazil, through military or civilian flights, cannot be discarded. The genus Chlorocoris Spinola is strictly New 
World in distribution (Thomas, 1985). They are large, conspicuous, and flat-bodied stink bugs, superficially resembling members of the genus Loxa Amyot \& Serville and Fecelia Stål, but lacking the spine on the superior apex of the femora. The genus contains at least 24 species, mostly from South America, Mexico, southern USA, and at least one species from Jamaica.

MATERIAL EXAMINED: PUERTO RICO. Aguadilla: Aeropuerto Borinquen. 6.xi.1978. Ramos, S. J. (ㅇ). JAR collection and donated [MEBT12605].

Species reported here increase the number of stink bug species present in Puerto Rico from 44 to 50, the number of genera from 29 to 34 . New reports include two new insect predators, with yet undetermined potential as pests or as biological control agents. We also present the first report of a subfamily Discocephaline on the island. An important question is raised as to whether these newly reported species represent uncommon natives or are recently invading species. Unfortunately, this cannot be determined solely from existing museum records. In that respect, perhaps the most salient of the species reported here is Alitocoris brunneus. The relative commonness of this stink bug in recent collections during the past decade, and its apparent complete absence from the historical MEBT collection before 2006, strongly suggest the possibility of a recent invasion.

\section{LITERATURE CITED}

Barber, H. G., 1923. A preliminary report on the Hemiptera: Heteroptera of Porto Rico collected by the American Museum of Natural History. Amer. Mus. Novit. 75: 1-13.

Barber, H. G., 1939. Insects of Porto Rico and the Virgin Islands: Hemiptera-Heteroptera (excepting the Miridae and Corixidae). Scientific Survey of Porto Rico and the Virgin Islands. N.Y. Academy of Sciences 14: 263-441.

De Clercq, P., 2000. Predaceous stink bugs (Pentatomidae: Asopinae). In: Heteroptera of Economic Importance. Eds: Schaefer, C. W. and A. R. Panizzi. CRC Press. Pp. 637-689.

De los Santos, G. and R. Bastardo, 2013. La familia Pentatomidae (Hemiptera: Heteroptera) en las colecciones de referencia de la República Dominicana. Novitates Caribaea. 6: $1-15$.

Distant, W. L., 1884. Insecta. Rhynchota, Hemiptera-Heteroptera. Pp. 36-37. In: Biologia Centrali-Americana. Eds: Godman, F. D. and O. Salvin. London, Vol. 1, xx + 462pp., $39 \mathrm{pls}$.

Fabricius, J. C., 1794. Entomologia systematica emendata et aucta secundum classes, ordines, genera, species adjectis synonymis, locis, observationibus, descriptionibus. C. G. Proft, Fil. et Soc., Hafniae. Vol. 4: 472 pp.

Fabricius, J. C., 1798. Entomologia systematica emendata et aucta, secundum classes, ordines, genera, species, adjectis synonymis, locis, observationibus. Supplementum. Proft et Storch, Hafniae, ii $+572 \mathrm{pp}$.

Franqui, R., A. Pantoja and S. Medina-Gaud, 1988. Host plants of pentatomids affecting rice fields in Puerto Rico. J. Agric. Univ. P.R. 72: 365-369. 
Garbelotto, T. de A., L. A. Campos and J. Grazia, 2011. A new synonymy in Alitocoris Sailer (Hemiptera, Pentatomidae, Discocephalinae). Rev. Brasileira Entomol. 55: 138-140.

Garbelotto, T. de A., L. A. Campos and J. Grazia, 2013. Cladistics and revision of Alitocoris with considerations on the phylogeny of the Herrichella clade (Hemiptera, Pentatomidae, Discocephalinae, Ochlerini). Zool. J. Linn. Soc. 168: 452472.

Haywood, P. J., B. Lancaster and D. Eastwood, 1994. Insects associated with, and some diseases of, Rottboellia cochinchinensis (Lour.) W.D. Clayton in Guyana. Proceedings - West Indies Sugar Technologists' $25^{\text {th }}$ Conference, Belize, April 18-21. Pp. 101-111.

Herrich-Schäffer, G. A. W., 1840. Die wanzenartigen insekten. C. H. Zehschen Buchhandlung, Nürnburg. 5(part 4): 69 .

McPherson, J. E., 1982. The Pentatomoidea (Hemiptera) of northeastern North America. Southern Illinois University Press. Carbondale and Edwardsville. 240p.

Panizzi, A. R., J. E. McPherson, D. G. James, M. Javahery and R. M. McPherson, 2000. Stink bugs (Pentatomidae). pp. 421-474. In: Heteroptera of Economic Importance. Ed: Schaefer, C.W. and A.R. Panizzi. CRC Press LLC.

Pérez-Gelabert, D. E. and D. B. Thomas, 2005. Stink bugs (Heteroptera: Pentatomidae) of the island of Hispaniola, with seven new species from the Dominican Republic. Bol. Soc. Entomol. Aragonesa 37: 391-352.

Rider, D. A., 1987. A new species of Acrosternum Fieber, subgenus Chinavia Orian, from Cuba (Hemiptera: Pentatomidae). J. New York Entomol. Soc. 95: 298-301.

Rider, D. A., 1988. A new species of Caribo Rolston from Puerto Rico (Hemiptera: Pentatomidae). Fla. Entomol. 71: 8-11.

Rider, D. A., 1992. Revision of Arocera, with the description of two new species (Heteroptera: Pentatomidae). J. New York Entomol. Soc. 100: 99-136.

Rider, D. A. and L. H. Rolston, 1995. Nomenclatural changes in the Pentatomidae (Hemiptera: Pentatomidae). Proc. Entomol. Soc. Wash. 97: 845-855.

Rolston, L. H., 1983. A revision of the genus Acrosternum Fieber, subgenus Chinavia Orian, in the Western (Hemiptera: Pentatomidae). J. New York Entomol. Soc. 91: 97-176.

Rolston, L. H. and F. J. D. McDonald, 1984. A conspectus of Pentatomini of the western hemisphere. Part 3 (Hemiptera: Pentatomidae). J. New York Entomol. Soc. 92: 69-86.

Rolston, L. H., 1986. The genus Cyptocephala Berg, 1883 (Hemiptera: Pentatomidae) J. New York Entomol. Soc. 94: 424-433.

Rolston, L. H., 1992. Key and diagnoses for the genera of Ochlerini (Hemiptera: Pentatomidae: Discocephalinae). J. New York Entomol. Soc. 100: 1-41.

Sailer, R. I., 1950. Alitocoris, a new genus of Pentatomidae (Hemiptera). Proc. Entomol. Soc. Wash. 52: 69-76.

Sailer, R. I., 1952. A revision of the stink bugs of the genus Mecidea. Proc. U.S. Nat. Mus. 102: 471-505.

Schuh, R. T. and J. A. Slater, 1995. True Bugs of the World (Hemiptera: Heteroptera). Classification and Natural History. Cornell University Press, Ithaca, New York. $336 \mathrm{pp}$.

Schwertener, C. F., G. S. Alburquerque and J. Grazia, 2002. Descrição dos estágios imaduros de Acrosternum (Chinavia) ubicum Rolston (Heteroptera: Pentatomidae) e efeito do alimento no tamanho e coloração das ninfas. Neotropical Entomol. 31: 571-579.

Segeren, P., 1982. Preliminary study on the vectors of "Hartrot" disease of coconut in Suriname. De Surinaamse Landbouw 30: 17-23.

Stål, C., 1870. Enumeratio Hemipterorum. Bidrag till en företeckning öfver alla hittils kända Hemiptera, jemte systematiska meddelanden. v1. Kongliga Svenska Vetenskaps-Akademiens Handlingar 9: 1-232.

Stoner, A., A. M. Metcalfe and R. E. Weeks, 1974. Plant feeding by a predaceous insect, Podisus acutissimus. Environ. Entomol. 3:187-189. 


\section{Segarra-Carmona et al./ Pentatomidae in Puerto Rico}

Spinola, M., 1837. Essai sur les insects Hemipteres, Rhyngotes, ou Heteropteres. Genoa, Yves Graviers, 383p.

Thomas, D. B., 1985. Revision of the genus Chlorocoris Spinola (Hemiptera: Pentatomidae). Entomol. Soc. Amer. Ann. 78:674-690.

Thomas, D. B., 1990. Menudo, a new genus of Pentatomidae (Heteroptera) from Puerto Rico. J. New York Entomol. Soc. 98: 424-428.

Thomas, D. B., 1992. Taxonomic Synopsis of the Asopinae Pentatomidae (Heteroptera) of the Western Hemisphere. Thomas Say Foundation Monographs, vol. 16.

Wolcott, G. N., 1948. The insects of Puerto Rico. Homoptera. J. Agric. Univ. P.R. 32(1): 1-416. 